\title{
MODEL AKSELERASI PENGEMBANGAN SAMBI SEBAGAI DESA WISATA DI YOGYAKARTA MELALUI RINTISAN PROGRAM NASIONAL PEMBERDAYAAN MASYARAKAT (PNPM) MANDIRI BIDANG PARIWISATA
}

\author{
Angela Ariani \\ NIDN: 0530106001 \\ e-mail: angela_301060@yahoo.co.uk \\ Dosen Sekolah Tinggi Pariwisata AMPTA Yogyakarta
}

\begin{abstract}
Accelerated Development in tourism of Sambi as tourism village has already done by applying the concept of community participation. Both in giving an important role to the community as the main actor and empowering them in the tourism developmental activities as well. The aspect of sustainability is also an important one.

The researcher finds a new model of accelerated development in tourism on Community-Based Tourism development. From the visual observation and in-depth interview with Mr. Haryono as the manager of Sambi tourism village, Mr. Sutarjo as the community working group coordinator and Mr. Hariman Yudo Raharjo as the chairman of Tourism and Culture Office of Sleman Regency, this research comes to an applicative tourism accelerated development model on Community-Based Tourism development at Sambi as tourism village which is the applicable one.
\end{abstract}

Keywords: Tourism Village, Sustainable Development, Community-Based Tourism, Community Empowerment

\section{PENDAHULUAN}

Mengutip definisi pariwisata dari publikasi berkala yang diterbitkan oleh World Tourism Organization (WTO), "Developing Sustainable Tourism" (1998:17): "Tourism is the activities of persons travelling to and staying in places outside oh their usual environment for not more than one consecutive year for leisure, business and other purposes", oleh penulis diterjemahkan secara bebas bahwa pariwisata adalah kegiatan yang dilakukan oleh orang-orang yang bepergian dan tinggal di luar tempat tinggalnya tidak lebih dari satu tahun secara terus-menerus, untuk tujuan memperoleh kesenangan, urusan bisnis maupun tujuan-tujuan lainnya.

Dan masih menurut World Tourism Organization (1998:18), "Tourism has become one of the world's most important sources of employment. It stimulates enormous investment of infrastructure, most of which also helps to improve the living conditions of local people", yang berarti bahwa pariwisata telah menjadi salah satu pencetak ketenagakerjaan yang penting dan sekaligus merangsang tumbuh dan berkembangnya penanaman modal di bidang fasilitas umum serta peningkatan kesejahteraan masyarakat lokal.

Pariwisata, sebagaimana dituliskan oleh Naisbitt (1997:3) dalam buku "Global Paradox", dapat dikategorikan sebagai industri terbesar dunia (the world's largest industry). Pentingnya peranan pariwisata dalam pembangunan ekonomi di berbagai negara sudah tidak diragukan lagi. Banyak negara sejak beberapa tahun terakhir menggarap sektor pariwisata dengan serius dan menjadikan pariwisata sebagai sektor unggulan.

Bagi Negara Indonesia, pariwisata merupakan bagian integral dari pembangunan nasional yang dilakukan secara sistematis, terencana, terpadu, berkelanjutan dan bertanggungjawab dengan tetap memberikan perlindungan terhadap nilai-nilai agama, budaya yang hidup dalam masyarakat, kelestarian dan mutu lingkungan hidup serta kepentingan nasional. Adapun penyelenggaraan kepariwisataan di Indonesia, menurut Undang-Undang Nomor 10 Tahun 2009 tentang Kepariwisataan, salah satunya bertujuan untuk memberdayakan masyarakat setempat, sedangkan yang dimaksud dengan masyarakat setempat adalah masyarakat yang bertempat tinggal di dalam wilayah destinasi pariwisata dan diprioritaskan untuk mendapatkan manfaat dari penyelenggaraan kepariwisataan di tempat tersebut.

Di dalam buku II Rencana Pembangunan Jangka Menengah Nasional (RPJMN) 2010 - 2014, khususnya pada bab III mengenai strategi pembangunan kepariwisataan adalah mengembangkan destinasi pariwisata dengan mendorong perbaikan dan peningkatan kualitas jaringan prasarana dan sarana pendukung pariwisata serta mengembangkan desa wisata melalui PNPM Mandiri (Rencana Strategis, Kementrian Budaya dan Pariwisata, 2010: 34). Lebih jauh lagi, sesuai dengan tugas pokok dan fungsi Kementrian Budaya dan Pariwisata melalui program pengembangan destinasi pariwisata, pemerintah telah menempatkan kegiatan pemberdayaan masyarakat di destinasi pariwisata pada prioritas ke-4 (dari 6 kegiatan yang diprioritaskan oleh pemerintah). Berdasarkan Rencana Strategis tersebut, salah satu model pengembangan pariwisata adalah pariwisata berbasis masyarakat atau community-based tourism (CBT), yang bertujuan untuk meningkatkan pemberdayaan masyarakat di pedesaan melalui PNPM Mandiri bidang 
pariwisata. Model pengembangan seperti ini bisa memberi berbagai keuntungan selain peningkatan pendapatan uang tunai, yaitu mendukung pembangunan berwawasan lingkungan hidup, pelestarian budaya lokal, pemberdayaan masyarakat, menambah sumber pendapatan masyarakat tanpa menciptakan ketergantungan pada satu usaha saja, dan pemerataan pendapatan di antara masyarakat. Pariwisata berbasis masyarakat adalah model pengembangan pariwisata dengan tingkat keterlibatan masyarakat setempat yang tinggi dan dapat dipertanggungjawabkan dari aspek sosial dan lingkungan hidup (Centre for International Forestry Research-CIFOR, 2004:1)

Desa wisata Sambi merupakan "desa alami asli Jogja" (demikian 'commercial branding' desa wisata Sambi) terletak di Jalan Kaliurang Km 19,2 Padukuhan Sambi, Desa Pakembinangun, Kecamatan Pakem, Kabupaten Sleman, Propinsi Daerah Istimewa Yogyakarta, yang menurut sejarahnya mulai dikembangkan pada tahun 2001 oleh Ibu Ir. Larasati Suliantoro, seorang praktisi pariwisata yang sudah banyak mengenyam asam garam di dunia pariwisata baik di Indonesia maupun di mancanegara. Dalam rangka mempersiapkan Sambi sebagai desa wisata, Ibu Ir. Larasati Suliantoro memberikan pembimbingan kepada para ibu kelompok Pemberdayaan Kesejahteraan Keluarga (PKK) Padukuhan Sambi tentang tata boga (tata cara pembuatan beraneka ragam masakan beserta cara penyajiannya). Dan dalam rangka memajukan serta meningkatkan pendapatan para ibu tersebut, apabila ada event pariwisata maka para ibu PKK tersebut dipercaya untuk membuat dan menyajikan berbagai kebutuhan konsumsi bagi para wisatawan. Bahkan sebelum terbentuknya desa wisata Sambi, sebenarnya Padukuhan Sambi sudah dikunjungi oleh wisatawan mancanegara dengan tujuan berwisata dengan cara menyewa dan tinggal di rumah penduduk.

Pengembangan selanjutnya tidaklah secara instan, yang artinya baru dikelola pada saat ada rencana kunjungan wisatawan dan kondisi desa kembali seperti semula pada saaat wisatawan meninggalkan desa, tetapi sebaliknya, pengelola selalu melibatkan masyarakat dalam pengembangan setiap saat melalui berbagai macam aktifitas keseharian masyarakat desa (living culture). Masyarakat desa bersama-sama mengelola dan mengatur desanya yang memiliki suasana pedesaan alami, sehingga layak ditawarkan kepada wisatawan, khususnya untuk menikmati hidup di alam pedesaan, termasuk melihat warga masyarakat sehari-hari dengan menginap di rumah warga yang dijadikan homestay. Wisatawan dilibatkan dalam aktifitas masyarakat sehari-hari, seperti: ikut mencangkul dan membajak tanah di sawah, menggarap hasil kerajinan, melihat dan terlibat aktif dalam pertunjukan kesenian tradisional atau acara seni budaya atau adat-istiadat daur hidup masyarakat yang masih dilestarikan oleh warga setempat.
Disamping itu, dalam rangka menindaklanjuti Program Nasional Pemberdayaan Masyarakat (PNPM) Mandiri, sebagai upaya pemerintah mempercepat penanggulangan kemiskinan, Departemen Kebudayaan dan Pariwisata melalui Direktorat Jenderal Pengembangan Destinasi Pariwisata telah melaksanakan program tersebut melalui pengembangan desa wisata. Sebagai embrio pelaksanaan kegiatan tersebut, maka pemerintah mulai tahun anggaran 2009 telah memprogramkan untuk pengembangan desa wisata di Propinsi DIY.

Berdasarkan pemikiran dan beberapa hal di atas, pemberdayaan masyarakat dalam pengembangan pariwisata menjadi sangatlah penting, dengan demikian masyarakat menjadi pusat perhatian dan pelaku utama yang tidak terpisahkan dalam pengembangan pariwisata.

Penelitian ini menjadi sangat strategis, karena diharapkan dapat mengungkapkan penerapan konsep aktif-partisipatoris masyarakat dalam pengembangan pariwisata, dan lebih lanjut bertujuan untuk merumuskan model akselerasi pengembangan pariwisata berbasis masyarakat di desa wisata Sambi. Artinya bahwa dengan mengembangkan model ini masyarakat akan lebih menyadari tentang adanya potensi wisata di desanya dan menyadari sepenuhnya mengenai dampaknya, seperti peningkatan di bidang ekonomi, semakin dilestarikannya nilai-nilai tradisional dan semakin dipeliharanya aset-aset wisata alam yang ada di desa Sambi. Dengan demikian, rumusan masalah: Bagaimana model akselerasi pengembangan pariwisata berbasis masyarakat di desa wisata Sambi? Secara rinci dan tegas tujuannya adalah mengungkapkan penerapan konsep aktif-partisipatoris masyarakat dalam pengembangan pariwisata di desa wisata Sambi dan merumuskan model akselerasi pengembangan pariwisata berbasis masyarakat di desa wisata Sambi.

\section{LITERATURE REVIEW}

Melihat kecenderungan perkembangan kepariwisataan yang lebih banyak melirik pada prisnip back to nature, maka pariwisata pedesaan merupakan suatu bentuk pariwisata dengan daya tarik berupa kehidupan desa yang dengan daya tarik khusus dalam masyarakatnya, yaitu keindahan alam dan budayanya. Kehidupan masyarakat desa yang dapat dijadikan sebagai destinasi wisata adalah sebagai obyek sekaligus subyek dari kepariwisataan, sebagai obyek maksudnya adalah bahwa kehidupan pedesaan merupakan tujuan bagi kegiatan wisata, sedangkan sebagai subyek adalah bahwa desa dengan segala aktivitas budayanya merupakan penyelenggara dari berbagai aktivitas kepariwisataan dan apa yang dihasilkan oleh kegiatan tersebut akan dinikmati oleh masyarakatnya secara langsung. Oleh karena itu, peran aktif dari masyarakat sangat menentukan kelangsungan kegiatan pariwisata di desa tersebut. 
Program Rintisan Secaranasional Untuk Desa Wisata

Program Nasional Pemberdayaan Masyarakat (PNPM) Mandiri Pariwisata ini adalah program rintisan. Seperti PNPM Mandiri yang dikembangkan oleh departemen lain, dana PNPM Mandiri Pariwisata ini juga langsung disalurkan kepada kelompok masyarakat dan tidak melewati jalur birokrasi. Ini untuk mengurangi kebocoran dana", demikian dikatakan oleh Menteri Kebudayaan dan Pariwisata Republik Indonesia, Jero Wacik, pada kesempatan acara peluncuran dana stimulan PNPM Mandiri Pariwisata di Singaraja, Bali pada 30 Juni 2011.

Tahun 2009 ini dalam rintisannya PNPM Mandiri Pariwisata diberikan kepada 104 desa di 17 propinsi yaitu: Sumut, Sumbar, Riau, Banten, DKI Jakarta, Jabar, Jateng, DIY, Jatim, Bali, NTB, NTT, Kalsel, Kalteng, Sulut, Sulsel, dan Sulawesi Tenggara, yang terdiri dari desadesa yang memiliki potensi pengembangan kegiatan kepariwisataan, dekat dengan daya tarik wisata, dan memiliki fasilitas pendukung pariwisata.

\section{Desa Wisata}

Salah satu model pemberdayaan ekonomi kerakyatan dalam bidang pariwisata adalah melalui pengembangan desa wisata. Perekonomian masyarakat pedesaan diangkat melalui kegiatan pariwisata, bahwa pariwisata dikembangkan berdasarkan unsur-unsur kegiatan yang telah ada di pedesaan serta ciri khas budaya setempat. Dengan kata lain pengembangan kegiatan pariwisata tidak terlepas dari ciri kegiatan masyarakat pedesaan yang telah ada, baik aspek ekonomi maupun sosial budaya (Direktur Jendral Pengembangan Produk Pariwisata, Yogyakarta 25 Oktober 2007).

Esensi desa wisata adalah pengembangan suatu wilayah (desa) dengan memanfaatkan kemampuan unsur-unsur yang ada dalam masyarakat dan desa yang berfungsi sebagai atribut produk wisata, menjadi suatu rangkaian aktivitas pariwisata yang terpadu dan memiliki tema. Pengertian dan terpadu disini adalah desa sebagai produk wisata mampu menyediakan dan memenuhi serangkaian kebutuhan perjalanan wisata, baik aspek daya tarik maupun berbagai fasilitas pendukungnya. Berangkat dari esensi ini, maka desa wisata dapat diartikan suatu wilayah pedesaan yang menawarkan keseluruhan suasana yang mencerminkan keaslian pedesaan, baik dari segi kehidupan sosial ekonomi, sosial budaya, adat istiadat keseharian, memiliki arsitektur bangunan dan struktur tata ruang desa yang khas, atau kegiatan perekonomian yang unik dan menarik, serta mempunyai potensi untuk dikembangkannya berbagai komponen kepariwisataan dan kebutuhan wisata lainnya. (Direktur Jendral Pengembangan Produk Pariwisata, Yogyakarta 25 Oktober 2007)

Selain itu, juga dapat dikatakan desa wisata adalah suatu bentuk integrasi antara atraksi, akomodasi dan fasilitas pendukung yang disajikan dalam suatu struktur kehidupan masyarakat yang menyatu dengan tata cara dan tradisi yang berlaku.

(http://id.wikipedia.org/wiki/Desa_wisata, 30 Nopember 2006).

\section{Pendekatan Pemberdayaan Masyarakat}

Secara etimologis pemberdayaan berasal dari kata dasar "daya" yang berarti kekuatan atau kemampuan . Pemberdayaan dapat dimaknai sebagai suatu proses menuju berdaya atau suatu proses untuk memperoleh daya atau kekuatan atau kemampuan dari pihak yang memiliki daya kepada pihak yang kurang atau belum berdaya.

Pemberdayaan masyarakat atau komunitas lokal merupakan paradigma yang sangat penting dalam kerangka pengembangan kepariwisataan. Menurut Adimiharja (1999) yang dikutip dalam Handout Diklat Lanjutan Pariwisata tentang "Pemberdayaan Masyarakat Melalui Kepariwisataan” (2010), pemberdayaan masyarakat tidak hanya mengembangkan potensi ekonomi rakyat saja, tetapi juga harkat dan martabat, rasa percaya diri dan harga dirinya, terpeliharanya tatanan nilai budaya setempat. Pemberdayaan sebagai konsep sosial budaya yang implementatif dalam pembangunan yang berpusat pada rakyat, tidak saja menumbuhkan dan mengembangkan nilai tambah ekonomi tetapi juga nilai tambah sosial budaya.

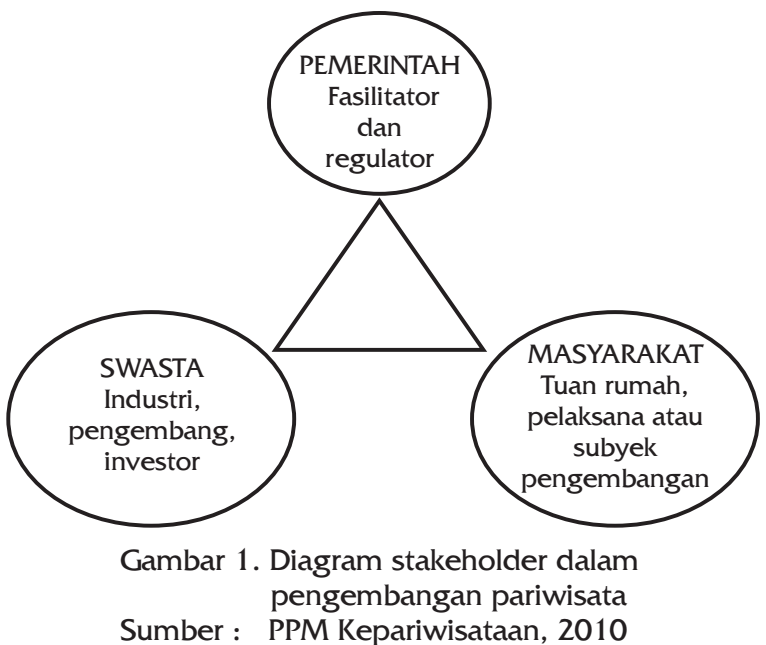

Community-Based Tourism (CBT)

Pariwisata berbasis masyarakat (Community-based Tourism) sebagai sebuah pendekatan pemberdayaan yang melibatkan dan meletakkan masyarakat sebagai pelaku penting dalam konteks paradigma baru pembangunan yaitu pembangunan yang berkelanjutan (sustainable development paradigm). Pariwisata berbasis masyarakat merupakan peluang untuk menggerakkan setiap potensi dan dinamika masyarakat, guna mengimbangi peran pelaku usaha pariwisata skala besar. Pariwisata berbasis masyarakat tidak berarti merupakan upaya kecil dan lokal, tetapi perlu diletakkan dalam konteks kerjasama masyarakat secara global (Sastrayuda, 2010:2). Dengan demikian, pariwisata berbasis masyarakat adalah pariwisata dimana masyarakat atau warga setempat memainkan peranan 
penting dan utama dalam pengambilan keputusan mempengaruhi dan memberi manfaat terhadap kehidupan dan lingkungan mereka.

Pemahaman tentang Community-Based Tourism adalah pariwisata yang menyadari keangsungan budaya, sosial dan lingkungan. Bentuk pariwisata ini dikelola dan dimiliki oleh masyarakat, untuk masyarakat, guna membantu para wisatawan untuk meningkatkan kesadaran mereka dan belajar tentang masyarakat dan tata cara hidup masyarakat lokal (the way of life). Dengan demikian CBT sangat berbeda dengan pariwisata massal (mass tourism). CBT merupakan model pengambangan pariwisata yang berasumsi bahwa pariwisata harus berangkat dari kesadaran nilai-nilai kebutuhan masyarakat sebagai upaya membangun pariwisata yang lebih bermanfaat bagi kebutuhan, inisiatif dan peluang masyarakat lokal. CBT bukanlah bisnis pariwisata yang bertujuan untuk memaksimalkan profit bagi investor tetapi lebih terkait dengan pariwisata bagi masyarakat dan sumber daya lingkungan (environmental resources). CBT lahir dari strategi pengembangan masyarakat dengan menggunakan pariwisata sebagai alat untuk memperkuat kemampuan organisasi masyarakat lokal.
Konsep CBT mempunyai prinsip-prinsip yang dapat digunakan sebagai tool of community development bagi masyarakat lokal, yaitu: (1) mengakui, mendukung dan mempromosikan pariwisata yang dimiliki masyarakat, (2) melibatkan anggota masyarakat sejak awal pada setiap aspek, (3) mempromosikan kebanggaan masyarakat, (4) meningkatkan kualitas hidup, (5) menjamin keberlanjutan lingkungan (environment sustainability), (6) memelihara karakter dan budaya lokal yang unik, (7) membantu mengembangkan cross-cultural learning, (8) menghormati perbedaan-perbedaan kultural dan kehormatan manusia, (9) mendistribusikan keuntungan secara adil di antara anggota masyarakat, dan (10) menyumbang persentase yang ditentukan bagi pendapatan masyarakat.

Konsep Pengembangan Pariwisata Berbasis Masyarakat

Konsep yang berarti definisi singkat dari sekelompok fakta atau gejala, merupakan unsur pokok dalam suatu penelitian. Dalam penelitian ini, peneliti menggunakan konsep tentang pengembangan pariwisata berbasis masyarakat, seperti pada tabel 1 berikut:

Tabel 1. Pengembangan Pariwisata Berbasis Masyarakat (Manajemen Komunitas)

\begin{tabular}{|c|c|c|c|}
\hline No & Keperluan Dasar & Kebijakan Dasar & Upaya-upaya \\
\hline 1. & $\begin{array}{l}\text { Membangkitkan semangat } \\
\text { masyarakat }\end{array}$ & $\begin{array}{l}\text { 1. Mendirikan badan pengelola } \\
\text { 2. Menjalin kerjasama dengan } \\
\text { pemerintah }\end{array}$ & $\begin{array}{l}\text { 1. Mengembangkan aktivitas } \\
\text { masyarakat } \\
\text { 2. Melaksanakan kegiatan adat } \\
\text { 3. Merencanakan event-event }\end{array}$ \\
\hline 2. & $\begin{array}{l}\text { Menjamin keberlangsungan } \\
\text { budaya, adat, perilaku } \\
\text { masyarakat, lingkungan } \\
\text { hidup, dan sumber daya } \\
\text { alam }\end{array}$ & $\begin{array}{l}\text { 1. Melestarikan budaya, adat } \\
\text { 2. Meningkatkan kualitas perilaku } \\
\text { masyarakat } \\
\text { 3. Merawat lingkungan hidup } \\
\text { 4. Memelihara sumber daya alam }\end{array}$ & $\begin{array}{l}\text { 1. Pelestarian budaya dan adat } \\
\text { 2. Meningkatkan keramahtamahan } \\
\text { 3. Konservasi dan meningkatkan } \\
\text { mutu lingkungan hidup } \\
\text { 4. Pengenalan usaha dan lapangan } \\
\text { kerja } \\
\text { 5. Menemukan sumber daya yang } \\
\text { baru } \\
\text { 6. Meningkatkan nilai sumber daya } \\
\text { 7. Menyeim ban g kan an ta a a } \\
\text { pemakaian dan konservasi }\end{array}$ \\
\hline 3. & $\begin{array}{l}\text { Membentuk suatu sistem } \\
\text { yang menyeimbangkan, } \\
\text { budaya, adat, perilaku } \\
\text { masyarakat, lingkungan } \\
\text { hidup, dan sumber daya } \\
\text { alam }\end{array}$ & $\begin{array}{l}\text { 1. Menyiapkan sistem informasi } \\
\text { dan komunikasi } \\
\text { 2. M e n y i a p k a n s i s t e m } \\
\text { pengembalian keuntungan } \\
\text { kepada masyarakat } \\
\text { 3. Melaksanakan evaluasi dan } \\
\text { monitoring }\end{array}$ & $\begin{array}{l}\text { 1. Merencanakan pengumpulan } \\
\text { informasi } \\
\text { 2. Menyiapkan data untuk } \\
\text { konservasi } \\
\text { 3. Menjamin pengembalian } \\
\text { keuntungankepadamasyarakat } \\
\text { 4. Mengusahakan pemerataan bagi } \\
\text { masyarakat } \\
\text { 5. Melakukan pengawasan } \\
\text { keuangan } \\
\text { 6. Melakukan pengawasan } \\
\text { pengembangan }\end{array}$ \\
\hline
\end{tabular}

\section{METODE PENELITIAN}

Dalam penelitian ini, penulis berupaya mengungkapkan penerapan konsep aktif-partisipatoris masyarakat dalam pengembangan pariwisata dan menganalisa model akselerasi pengembangan pariwisata berbasis masyarakat dalam konteks pengembangan Sambi sebagai desa wisata di Yogyakarta.

Penelitian dilakukan di suatu kawasan wisata alam dan budaya, yaitu Desa Wisata Sambi, sebagai wilayah 
amatan. Wilayah amatan adalah perkembangan kondisi fisik dan non-fisik desa wisata Sambi, yang secara administratif berlokasi di jalan Kaliurang Km 19,2 dusun Sambi, kelurahan Pakembinangun, Kecamatan Pekem, Kabupaten Sleman, Yogyakarta. Sasaran yang akan diamati terdiri dari pengamatan fisik dan pengamatan non-fisik. Pengamatan fisik dilakukan di desa wisata Sambi, seperti topografi, geografi, daya tarik wisata dan sedangkan pengamatan non-fisik adalah peran serta aktif dan keterlibatan masyarakat, sebagai mitra sejajar dalam kepariwisataan sejak perencanaan, pelaksanaan sampai dengan evaluasi dan pengawasan pengembangan dan pemerintah daerah dalam pengembangannya. Alasan penulis mengambil lokasi di kawasan tersebut, karena adanya permasalahan yang menarik perhatian untuk diteliti, dengan waktu penelitian bulan Januari 2011 sampai dengan Agustus 2011

Pemilihan obyek tersebut didasarkan atas pertimbangan-pertimbangan sebagai berikut: Desa Wisata Sambi sebagai daya tarik wisata di wilayah Kabupaten Sleman yang menjadi daerah tujuan wisatawan, dengan kriteria 'desa wisata mandiri', dan sekaligus merupakan 'vocal point' di kawasan desa wisata Sambi, karena selain itu ada daya tarik lain yang sifatnya melengkapi, yaitu Ledok Sambi Recreation \& Experiential Learning dan Sambi Resort-resto-spa. Keberadaannya yang diharapkan dapat menjadi daya tarik wisata alternatif dan sekaligus daya tarik wisata minat khusus bagi para wisatawan minat khusus, belum mampu berkembang secara maksimal

Keberhasilan desa wisata Sambi yang diakui oleh pemerintah sebagai desa wisata mandiri, ditandai dengan diluncurkannya bantuan stimulan dari pemerintah pusat melalui Program Nasional Pemberdayaan Masyarakat (PNPM) Mandiri bidang pariwisata pada kurun waktu 3 (tiga) tahun terakhir secara terus-menerus, yaitu 2009, 2010 dan 2011.

Sumber data yang paling menentukan dalam penelitian ini adalah gejala yang terjadi dan sifatnya aktual serta instrumentasi utama dilakukan oleh peneliti, karena peneliti merupakan instrumen utama sekaligus pengumpul data primer yang utama, tetapi literatur tetap diperlukan. Selain peneliti, sumber data lain adalah informan, data yang diperoleh berjenis data primer, yaitu data yang dikumpulkan langsung oleh peneliti dan para informan melalui metode wawancara, observasi dan bukan dari pengumpulan data yang pernah dilakukan sebelumnya. Sumber data yang lain adalah berbagai macam media cetak, jurnal ilmiah, naskah serta dokumen yang mendukung penelitian ini, artinya data yang sudah dalam bentuk jadi yang berhubungan dengan masalah penelitian yang digunakan sebagai pelengkap dan pendukung data primer, data yang diperoleh berjenis data sekunder.

Analisis Aktif-partisipatoris Masyarakat Dalam Pengembangan Pariwisatadi Desa WisataSambi

Kunci pokok konsep aktif-partisipatoris dalam pengembangan pariwisata adalah pelibatan masyarakat pada kegiatan-kegiatan pengembangan sebanyak dan seberagam mungkin serta secara interaktif. Partisipasi interaktif masyarakat sebagai peserta kegiatan akan mendorong invovasi pribadi dan mendorong terbentuknya kerjasama untuk menciptakan sistem pembelajaran yang efektif.

Wujud nyata pendapat di atas yang terjadi di desa wisata Sambi, dalam analisis ini penulis deskripsikan melalui suatu event yang pernah dilaksanakan di desa wisata Sambi dengan dukungan yang bernilai tinggi dari masyarakat setempat, yaitu suatu bentuk kegiatan yang dilaksanakan yang bertajuk "Short Grand Work (SGW), Desa Wisata Sambi - Gathering" di Ledok Sambi Reacreational \& Experiential Learning oleh rombongan dari SMU dari Jakarta, pada tanggal 14 - 16 Desember 2009. Hal tersebut dibuktikan dengan ilustrasi: "Dimulai dari tahapan persiapan kegiatan, seluruh masyarakat menyambut gembira, dengan cara bersedia terlibat dalam setiap jenis kegiatan yang diprogramkan. Diawali dengan penjelasan kegiatan, tugas dan peran kelompok kerja lapangan berdasarkan program yang disusun sampai dengan pelaksanaannya terlihat bisa diselesaikan oleh masyarakat dengan baik. Pengelola desa wisata Sambi berjalan bersama dengan masyarakat dalam hubungan kerja yang sejajar. Dan terbukti kegiatan itu bisa berakhir dengan sukses".

Dari pelaksanaan kegiatan tersebut, bisa dilihat secara nyata peran masing-masing kelompok masyarakat yang terlibat dan bisa memberikan kontribusi yang sangat berarti bagi terlaksananya kegiatan itu. Dan lebih lanjut beliau menyatakan rasa bangga atas partisipasi aktif masyarakat untuk secara bersama-sama terlibat mendukung lancarnya kegiatan. Pengelola bersama dengan masyarakat desa wisata Sambi berinisiatif untuk membangun, dengan pengelolaan internal desa wisata Sambi, sebuah fasilitas untuk outbound activity yang berada di lokasi dekat kantor sekretariat pengelola. Luas area sekitar $100 \mathrm{~m} 2$ dan dimiliki oleh desa, sudah mulai dibangun dan dilengkapi dengan aneka games khusus untuk kelompok usia anak-anak. Dengan pembangunan bertahap dan untuk mengantisipasi luapan pengunjung pada saat hari raya Idul Fitri 2011, diperkirakan sudah bisa diwujudkan adanya tambahan arena permainan yang tidak saja untuk kelompok usia anak-anak, tetapi juga kelompok usia dewasa. Tentunya untuk mewujudkan harapan ini ditempuh dengan kerja gotong-royong, mengajak masyarakat secara umum (dengan dikoordinir oleh Koordinator Kelompok Kerja Lapangan) menyelesaikan pembangunan fasilitas outbound. Pendanaan untuk menambah fasilitas fisik ini, dilakukan oleh pengelola desa wisata Sambi dengan menggunakan Dana Bantuan Desa wisata melalui PNPM Mandiri Pariwisata tahun anggaran 2011.

Pandangan yang sedikit berbeda mengenai partisipasi masyarakat secara nyata ini dikemukakan ibu Umi Salamah selaku koordinator kelompok membatik (seluruh anggota kelompok adalah ibu, baik yangbekerja di luar rumah atau ibu rumah tangga) bahwa: "Saya sangat setuju dan merasakan sekali keterlibatan masyarakat dalam pengembangan pariwisata di desa 
wisata Sambi, yang menurutnya diistilahkan sebagai 'proyek masyarakat' sehingga masyarakat merasakan bagi hasil dari kegiatan yang dilakukan dalam kelompok. Selain dari keuntungan financial yang didapatkan juga dari skill yang diperoleh melalui kegiatan membatik di kelompoknya".

Lebih lanjut dinyatakan bahwa kelompok masyarakat yang berpartisipasi tidak dipaksa oleh siapapun, tetapi partisipasi aktif mereka betul-betul didasarkan pada kesungguhan untuk bersedia dilibatkan dan dengan penuh tanggung jawab. Hal ini jelas terlihat dalam kelompok yang dipimpinnya, ibu-ibu dengan rela meninggalkan pekerjaan sehari-hari atau dengan cara nyambi (artinya melakukan pekerjaan lain di sela kegiatan pokoknya di rumah) mengikuti pelatihan membatik dan melayani tamu saat berkunjunng ke desa wisata Sambi dengan sukarela dan dengan senang hati. Terlebih karena mereka sungguh merasakan dan mengalami manfaat ekonomis, yaitu perbaikan taraf hidup keluarga. Bentuk partisipasi masyarakat sangat beragam, baik secara perorangan maupun berkelompok.

Berdasarkan pemaparan di atas, dapat disimpulkan bahwa penerapan konsep aktif-partisipatoris masyarakat dalam pengembangan pariwisata di desa wisata Sambi dalam setiap tahapan prosesnya sudah berjalan dengan baik. Bentuk kegiatan yang dilaksanakan sudah mengarah kepada bentuk pariwisata yang memberikan kesempatan kepada masyarakat lokal untuk terlibat dalam kegiatan pengembangan pariwisata, adanya kepemimpinan yang kompeten di bidang pariwisata, ditandai dengan dirasakan adanya peningkatan terhadap pengelolaan desa wisata Sambi dibandingkan tahun sebelumnya dan diaktifkannya koordinator kelompok kerja lapangan yang menangani segala bidang kerja, masyarakat yang tidak terlibat secara langsung dalam usaha pariwisata juga memperoleh keuntungan, terlaksananya kegiatan yang diikuti oleh siswa SMU dari Jakarta itupun menuntut pemberdayaan masyarakat dalam setiap kegiatan. Dengan demikian prinsip-prinsip dalam konsep aktifpartisipatoris masyarakat dalam pengembangan pariwisata sudah diterapkan di desa wisata Sambi.

\section{Analisis Model Akselerasi Pengembangan Pariwisata Berbasis Masyarakat di Desa Wisata Sambi}

Pengembangan pariwisata berbasis masyarakat di desa wisata Sambi merupakan prinsip pembangunan pariwisata berkelanjutan, yang menekankan keterlibatan masyarakat secara langsung pada seluruh kegiatan pariwisata. Namun, masih ada kelompok masyarakat di desa wisata Sambi yang merasa belum 'tersentuh' adanya kagiatan pengembangan pariwisata, sehingga memunculkan kecemburuan sosial.

Dengan demikian, pengembangan pariwisata berbasis masyarakat merupakan hal yang sangat penting diperhatikan oleh seluruh lapisan masyarakat di desa wisata Sambi. Pengelola telah berupaya semaksimal mungkin untuk menyadarkan akan pentingnya peran perorangan dalam setiap kegiatan yang dijalankan.
Demikian juga, masyarakat desa wisata Sambi pun memahami pariwisata secara utuh dan mendalam, mampu menempatkan diri menjadi bagian dari pengembangan pariwisata yang terjadi serta masyarakat mampu menangkap setiap peluang yang ada.

Strategi memposisikan masyarakat pada tingkatan yang utama menjadi subyek dalam pengembangan pariwisata di desa wisata Sambi dan memberikan peluang yang seluas-luasnya kepada masyarakat untuk ikut berinovasi dan mendukung segala program yang dilaksanakan oleh pengelola desa wisata Sambi. Dengan membangun kesadaran masyarakat terhadap keberadaan desa wisata Sambi maka masyarakat menjadi sangat protektif terhadap lingkungan alam dengan segala jenis sumber daya dan pelestarian budaya yang dimiliki. Antusias masyarakat di desa wisata Sambi untuk melestarikan tata cara dan adat istiadat masyarakat sangatlah tinggi, karena masyarakat desa wisata Sambi sangat menyadari bahwa itu semua merupakan kewajiban yang harus mereka laksanakan. Hal ini dipertegas lagi oleh Ketua pengelola desa wisata Sambi: "Kami bangga terhadap sebagian warga desa yang pernah berdomisili di desa wisata Sambi dan sekarang bekerja di tempat atau kota lain, secara bersama-sama masih melestarikan tradisi keagamaan yang bermuatan kearifan lokal (local wisdom), melaksanakan acara ritual tradisional yaitu nyadran bersama pada tanggal 21 Ruwah (hitungan bulan Jawa) yang secara internasional jatuh pada hari Sabtu 23 Juli 2011. Dan untuk acara sejenis pada tahun-tahun lalu, merekalah yang menyelesaikan segala urusan finansial, sehingga masyarakat yang saat sekarang ini masih berdomisili di desa wisata Sambi secara bersama-sama mempersiapkan segala sesuatunya, terlebih konsumsi untuk semua masyarakat yang mengikuti acara tersebut".

Mengacu pendapat Nicole Hausler dalam "Planning for Community-Based Tourism, A Complex and Challenging Task", 2001, bahwa "Community-Based Tourism is a type of tourism run by and for local communities with a high level of participation", yang disederhanakan artinya menjadi: pariwisata berbasis masyarakat merupakan suatu bentuk pariwisata oleh, dari dan untuk masyarakat setempat, dan menuntut tingkat partisipasi masyarakat yang tinggi. Pandangan mengenai pariwisata berbasis masyarakat menurut Nicole Hausler ini sejalan dengan pandangan dari Pariwisata Inti Rakyat (PIR) atau Core Tourism People, yang digunakan oleh peneliti sebagai model pengembangan pariwisata dalam pembahasan ini, yaitu model pengembangan pariwisata yang menempatkan masyarakat sebagai bagian yang tidak terpisahkan dari produk wisata dan pemahaman bahwa produk wisata merupakan proses rekayasa sosial masyarakat. Model ini diyakini mampu menciptakan produk wisata yang mencirikan lokal sebagai modal dasar perencanaan produk, di lain pihak juga akan dapat menciptakan ketahanan dan kestabilan sosio ekonomi masyarakat. Dengan kata lain pariwisata berbasis masyarakat 
merupakan bentuk pariwisata yang memperhitungkan aspek keberlanjutan lingkungan, sosial dan budaya, juga sekaligus sebagai alat konservasi lingkungan.

Dengan demikian, dalam analisis ini peneliti meyakini bahwa dimensi-dimensi yang dianggap penting dalam pariwisata berbasis masyarakat dan berpola PIR di desa wisata Sambi meliputi: (1) dimensi ekonomi, dengan indikator yang nampak sekali adalah bertambahnya penghasilan keluarga, bertambahnya wawasan untuk menjalankan usaha, mengubah pola piker masyarakat dalam berbisnis, semakin bertambahnya peluang sumber dana bagi masyarakat, (2) dimensi sosial, dengan indikator yang signifikan adalah meningkatnya kualitas hidup masyarakat, mengembangkan aktifitas masyarakat desa wisata Sambi, merencanakan berbagai macam event, pengenalan usaha dan lapangan kerja, peningkatan kebanggaan komunitas, pembagian peran antara lakilaki dan perempuan secara adil (gender), (3) dimensi budaya, dengan indikator yang nampak adalah bahwa masyarakat di desa wisata Sambi melestarikan upacara adat tradisional dan keagamaan, mempertahankan seni dan budaya lokal, meningkatkan keramahtamahan dalam melayani tamu (4) dimensi lingkungan, dengan indikator mengatur pembuangan sampah, meningkatnya kepedulian masyarakat dalam kebersihan lingkungan, memperhatikan keindahan halaman rumah, pembelajaran tentang konservasi dan peningkatan kualitas lingkungan hidup, meningkatkan nilai sumber daya, menemukan sumber daya baru, dan sebagai kelengkapannya adalah (5) dimensi politik, dengan indikator meningkatnya partisipasi masyarakat lokal dan menjamin hak-hak dalam pengelolaan sumber daya alam yang terdapat di desa wisata Sambi, menjamin pengembalian keuntungan kepada masyarakat, mengusahakan pemerataan bagi masyarakat desa wisata Sambi.

Berdasarkan uraian dan hasil pengamatan peneliti serta hasil wawancara, bisa disimpulkan bahwa ada empat konsep aktif-partisipatoris masyarakat yang sudah diterapkan dalam pengembangan pariwisata di desa wisata Sambi, yaitu: (1) bentuk kegiatan yang dilaksanakan di desa wisata Sambi sudah mengarah kepada bentuk pariwisata yang memberikan kesempatan kepada masyarakat lokal untuk terlibat dalam kegiatan pengembangan pariwisata, (2) adanya kepemimpinan yang kompeten di bidang pariwisata, ditandai dengan dirasakan adanya peningkatan terhadap pengelolaan desa wisata Sambi dibandingkan tahun sebelumnya dan diaktifkannya koordinator kelompok kerja lapangan yang menangani segala bidang kerja, (3) masyarakat yang tidak terlibat secara langsung dalam usaha pariwisata juga memperoleh keuntungan, dan (4) mengutamakan pemberdayaan masyarakat, merupakan konsep yang bersifat holistik dan perlu digali secara terus-menerus, mulai dari usia anak, remaja, dewasa sampai manula (manusia lanjut usia) tetap perlu diberdayakan dan diberi pemahaman. Disamping penerapan konsep tersebut, pengembangan pariwisata yang dilakukan di desa wisata Sambi dengan tetap mengutamakan ketersediaan potensi wisata yang ada dan menggali potensi baru serta mengarah pada pengembangan pariwisata yang berkelanjutan (sustainable tourism development) sebagai suatu paradigma baru dalam pengembangan pariwisata yang mengandalkan ketersediaan sumber daya alam (yang pada suatu saat kelak akan habis), dalam arti pengembangan yang sesuai dengan kebutuhan wisatawan dengan tetap memperhatikan kelestarian dan memberi peluang kepada generasi muda untuk memanfaatkan dan mengembangkannya. Dan pada akhirnya melalui analisis ini, bisa dirumuskan suatu model akselerasi pengembangan pariwisata berbasis masyarakat yang sesuai dengan kondisi di desa wisata Sambi, yaitu dengan cara meletakkan secara proporsional masyarakat sebagai aspek dominan dan potensial atau sebagai subyek dan bukan obyek dalam setiap aktifitas pengembangan dengan tetap berlandaskan pada aspek keberlanjutan di segala bidang, seperti yang peneliti gambarkan sebagai berikut

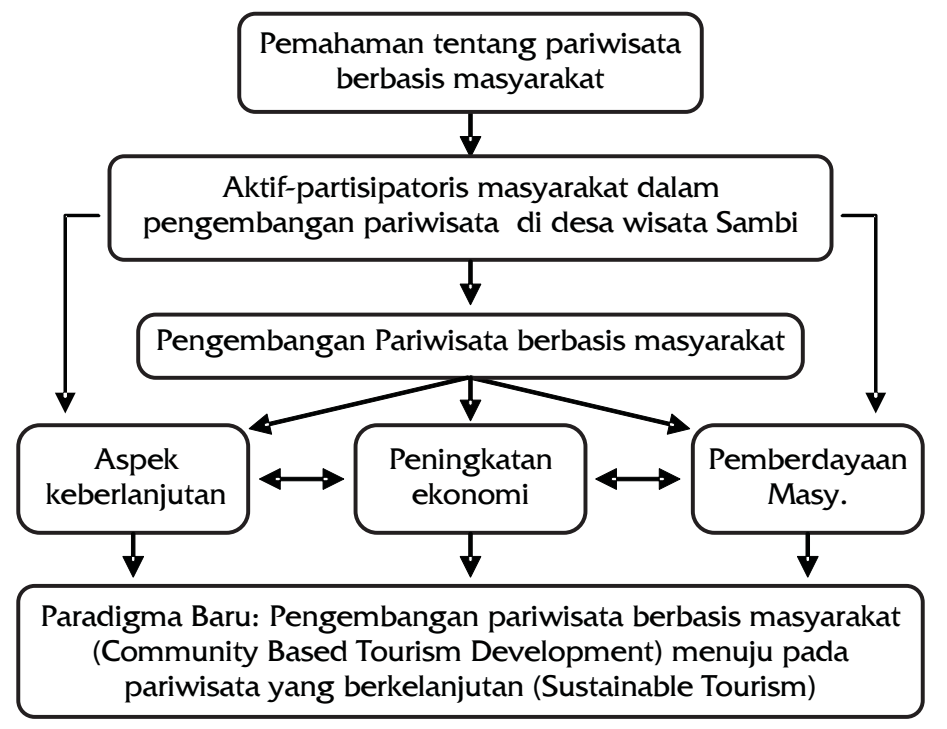

Gambar 2. Model Akselerasi Pengembangan Pariwisata Berbasis Masyarakat 
Pariwisata berbasis masyarakat sebagai sebuah pendekatan pemberdayaan yang melibatkan dan meletakkan masyarakat sebagai pelaku penting dalam konteks paradigma baru pembangunan yaitu pembangunan yang berkelanjutan (sustainable development paradigm), yang sekaligus merupakan peluang untuk menggerakkan setiap potensi dan dinamika masyarakat. Untuk mewujudkan paradigma baru tersebut, diperlukan adanya sinergi antara pemerintah dengan masyarakat, sebagai pelaku utama dalam pendekatan ini. Bagaimanapun juga, partisipasi masyarakat merupakan elemen pokok dalam model ini.

Sebelum pembahasan mengenai aktif-partisipatoris masyarakat dalam pengembangan pariwisata di desa wisata Sambi, terlebih dahulu dimantapkan pemahaman tentang makna pengembangan pariwisata berbasis masyarakat. Partisipasi masyarakat yang dijadikan fundamen pokok dalam pemberdayaan masyarakat di desa wisata Sambi menjadi elemen penting dalam model pengembangan pariwisata berbasis masyarakat. Pada tataran pengembangan pariwisata, masyarakat desa wisata Sambi perlu menyadari kepemilikan potensi wisata dan aksesibilitas yang ada di desa wisata tersebut. Adapun tujuan yang ingin dicapai adalah terwujudnya peningkatan ekonomi masyarakat setempat dengan tidak mengesampingkan aspek keberlanjutan, yang pada akhirnya demi terwujudnya pembangunan berkelanjutan, yang pada umumnya mempunyai sasaran memberikan manfaat bagi generasi sekarang tanpa mengurangi manfaat bagi generasi mendatang

Dengan demikian bahwa pariwisata berkelanjutan harus bertitik tolak dari kepentingan dan partisipatif masyarakat untuk dapat memenuhi kebutuhan wisatawan atau pengunjung sehingga meningkatkan kesejahteraan masyarakat, dengan kata lain bahwa pengelolaan sumberdaya yang ada di desa wisata Sambi dilakukan sedemikian rupa sehingga kebutuhan ekonomi sosial masyarakat dapat terpenuhi.

\section{KESIMPULAN}

Rumusan model akselerasi pengembangan pariwisata di desa wisata Sambi yang dihasilkan adalah suatu model dengan cara meletakkan secara proporsional masyarakat sebagai aspek dominan dan potensial atau sebagai subyek dan bukan obyek dalam setiap aktifitas pengembangan engan tetap berlandaskan pada aspek keberlanjutan di segala bidang, yang sekiranya bisa diterapkan, yang berarti bahwa dengan menerapkan model pengambangan tersebut, masyarakat lebih menyadari tentang pentingnya partisipasi aktif dalam setiap aspek kegiatan pengembangan pariwisata yang dilakukan di desa wisata Sambi serta menyadari sepenuhnya mengenai dampak pengembangan pariwisata itu terhadap aspek sosial, ekonimi dan lingkungan di desa wisata Sambi.

Penerapan konsep aktif-partisipatoris masyarakat dalam pengembangan pariwisata di desa wisata Sambi dalam setiap tahapan prosesnya sudah berjalan dengan baik. Bentuk kegiatan yang dilaksanakan sudah mengarah kepada bentuk pariwisata yang memberikan kesempatan kepada masyarakat lokal untuk terlibat dalam kegiatan pengembangan pariwisata, adanya kepemimpinan yang kompeten di bidang pariwisata yang ditandai dengan dirasakan adanya peningkatan terhadap pengelolaan desa wisata Sambi dibandingkan tahun sebelumnya dan diaktifkannya koordinator kelompok kerja lapangan yang menangani segala bidang kerja, masyarakat yang tidak terlibat secara langsung dalam usaha pariwisata juga memperoleh keuntungan, terlaksananya kegiatan sangat menuntut pemberdayaan masyarakat.

\section{REFERENSI}

Afiffudin, H. dan Beni Ahmad Saebani. 2009. Metodologi Penelitian Kualitatif. Bandung: Pustaka Setia.

Ardika, I Gede. 1999. Acara Pencanangan Program Desa Wisata oleh Presiden Republik Indonesia pada tanggal 27 September 1999, Jakarta

Agenda 21. 1992. The Travel Tourism Industry: Towards Environmentaly Sustainable Development, WITC, WTO, The Earth Council.

Basuki, Ari.1992. Desa Wisata Penglipuran: Suatu Penataan Desa Tradisional di Bali. Tesis

CIFOR (Centre for International Forestry Research). 2004.Pembangunan Pariwisata Berbasis Masyarakat, Paper disajikan pada CIFOR Conference, Jakarta

Cohen dan Uphoff. 1977.Rural Development Participation, New York, Cornell University

Conyers, Diana.1991. An Introduction To Social Planning In The Third World, terjemahan Susetiawan, Perencanaan Sosial di Dunia Ketiga: Suatu Pengantar. Yogyakarta: Gadjah Mada University Press,

Dwiloka, Bambang dan Riana.2005. Teknik Menulis Karya Ilmiah: Skripsi, Tesis, Disertasi,Artikel, Makalah dan Laporan, Rineka Cipta. Jakarta

Fandeli, Chafid, Raharjana Titi Destha, Kaharuddin.2003.Pengembangan kawasan pedesaan sebagai obyek wisata. Tesis, Puspar UGM

Fandeli, Chafid dan Nurdin, Muhammad.2005. Pengembangan Ekowisata Berbasis Konservasi Di Taman Nasional. Kerjasama Fakultas Kehutanan UGM Yogyakarta, Pusat Studi Pariwisata UGM Yogyakarta dan Kantor Kementrian Lingkungan Hidup. Tesis. tidak dipublikasikan

Garrod, Brian. 2001. Local Participation in the Planning and Management of Eco-tourism: A Revised Model Approach, Bristol: University of the West of England

Hausler, Nicole. 2001. Planning for Community-Based Tourism: A Complex and Challenging Task, The International Ecotourism Society, England

Innayatullah, Benni. 2011. Pariwisata dan masyarakat. www. google.com. Pariwista Berbasis Komunitas. 
Kementrian Kebudayaan dan Pariwisata Republik Indonesia. 2010.Peraturan Menteri Kebuidayaan dan Pariwisata tentang Rencana Strategis, Tahun 2010-2014, Jakarta

Kusmayadi dan Endar Sugiarto. 2000. Metodologi Penelitian Dalam Bidang Kepariwisataan. PT. Gramedia Jakarta

Marpaung. 2010. Pengantar Ilmu Pariwisata, Gramedia, Jakarta

Moleong, L.J. 2010. Metodologi Penelitian Kualitatif, Edisi Revisi, Rosdakarya, Bandung

Murphy. 1985. P.E. Tourism: A Community Approach, Methuen, London

Naisbitt, Jhon. 1977. Global Paradox, Binarupa Aksara (terjemahan), Jakarta

Nasikun. 2000.Globalisasi dan Paradigma Baru Pengembangan Pariwisata Berbasis Komunitas. Paper disajikan dalam Seminar Pariwisata di UGM. Yogyakarta

Nurtjahjo, Agus, T.P. 1994. Partisipasi Masyarakat Sekitar Hutan Lindung Dalam Kegiatan Reboisasi, Tesis. Yogyakarta: UGM.

Raharjana, Dhesta T. 2001.Pengembangan Desa Wisata Berbasis Budaya (Kajian Etnoekologi Masyarakat Dusun Ketingan, Desa Tirtoadi, Kecamatan Mlati, Kabupaten Sleman, Daerah Istimewa Yogyakarta), Tesis. Yogyakarta: UGM,

Rindrasih, Erda. 2004.Prospek Pengembangan Kawasan Kalibayem Pasca Bencana Banjir Untuk Pengembangan Kepariwisataan Berbasis Masyarakat di Kabupaten Bantul, Skripsi tidak dipublikasikan. Yogyakarta: UGM,

Sastrayuda, G.S. 2010. Hand out mata kuliah Concept Resort \& Leisure, Strategi Pengembangan dan Pengelolaan Resort \& Leisure, Jakarta

Sastopoetro, Santoso, R.A. 1988.Partisipasi, Komunikasi, Persuasi dan Disiplin Dalam Pembangunan Nasional. Bandung: Alumni,

Soekadijo. 1997. Anatomi Pariwisata, Gramedia, Jakarta

Stephen J.Page, Don Getz. 1996. Bisnis Pariwisata Pedesaan: Perspektif Internasional, Milik Negara Tidak diperdagangkan. International Thomson Business

Suansri, Potjana. 2003.Community Based Tourism Handbook, Thailand: REST Project

Subagyo. 1991.Pengembangan Pariwisata Pedesaan. Yogyakarta: Andi,

Suwantoro, Gamal. 2000.Pengantar Pariwisata. Bandung: Rosdakarya.

Timothy, D.J. 1999.Participatory Planning: A View of Tourism in Indonesia. Annual Review of Tourism Research. XXVI

Weber, Helmut. 2004. Ekonomi Pengembangan Community Based Tourism. Yogyakarta

Wirartha, I Made. 2006. Pedoman Penulisan Usulan Penelitian, Skripsi dan Tesis, Yogyakarta: Andi
World Tourism Organization. 1998. Guide for Local Authorities on Developing Sustainable Tourism. Monthly Publication of Tourism and Environment

Yaman, Amat Ramsa \& A. Mohd. 2004. Community Based Ecotourism: New Proportion for Sustainable Development and Environment Conservation in Malaysia. Journal of Applied Sciences, Vol. IV No. 1: 44-68

Yoeti, Oka A. 2001.Pariwisata: Sebuah Ilmu. Yogyakarta: Andi,

http://www. google.com/Desa Wisata

http://www. google.com/Pariwisata Berbasis Komunitas

http://id.wikipedia.org/wiki/Desa 